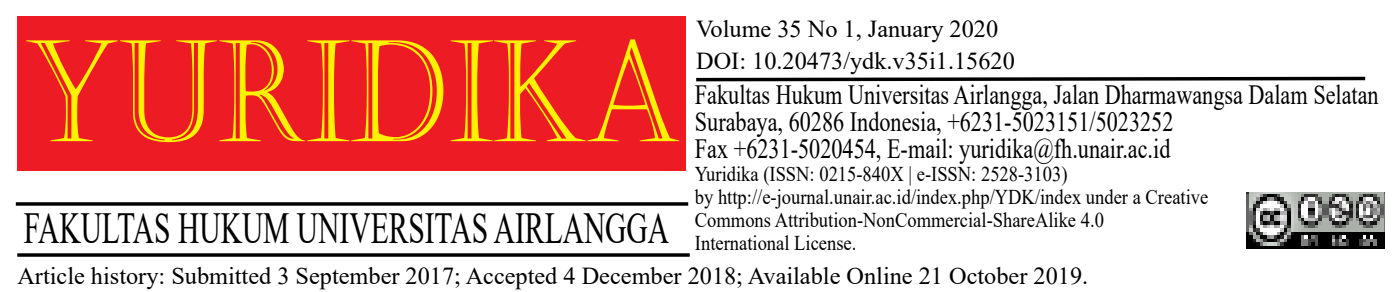

\title{
Late Payment Penalty: Ta'widh and Gharamah Imposed to Debtor from the Shariah Perspective
}

\author{
Zuhaira Nadiah Binti Zulkipli \\ zuhairanadiah@uitm.edu.my \\ Universiti Teknologi Mara, Malaysia
}

\begin{abstract}
Islamic financial institutions had face problems and barriers such as the problem of delayed financing settlement (for any reason), where it is not possible to impose any interest due to the delay or the cessation of settlement which practiced in conventional banks due to riba' prohibited (haram) in Shariah principles. This situation is more detrimental when some customers who purposely delay payment of their debts or purposely refuse to pay due to the absence of rules concerning penalty for late payment in Islamic banks. As a result, the Islamic banks had failed to achieve their targeted profits when the problem of debt payment occurs, the Islamic banks have to bear all the losses and finally face difficulties in achieving sustainability and lose out in their efforts to compete with the conventional banks which accept time-based interest for every default late payments of debts. This study aims to discuss the permissibility of late payment charges by way of ta'widh and gharamah from the Shariah perspective and to find the applicable law in Malaysia. Besides, the implementation of ta'widh and gharamah can be described as in the resolutions of the Shariah Advisory Council of Bank Negara Malaysia (SAC). Further, it will elaborate on how related this late payment charges with the concepts of Shariah, Maqasid of Shariah and Maslahah according to the judgement of the fundamentals of the Islamic Jurispendence. Lastly, it will also discuss how the imposition of ta'widh and gharamah is different from riba for deferred debts in Islamic financial institutions.
\end{abstract}

Keywords: Late Payment Penalty; Ta'widh and Gharamah; Shariah; Riba.

\section{Introduction}

In Malaysia, the highest Shariah regulatory body for Islamic banking and financial institutions is the SAC BNM. ${ }^{1}$ Through its series of meetings as held on 14th February 1998, 28th January 2010 and 20th May 2010 SAC BNM also have resolved that the late payment charges imposed by an Islamic financial 
institution encompassing both concepts of gharamah (fine or penalty) and ta widh (compensation) are permissible, subject to four conditions as follows :

1. Ta 'widh may be charged on late payment of financial obligations resulting from exchange contracts (such as sale and lease) and qard;

2. Ta 'widh may only be imposed after the settlement date of the financing became due as agreed between both contracting parties;

3. Islamic financial institutions may recognize $t a$ widh as income on the basis that it is charged as compensation for actual loss suffered by the institution; and

4. Gharamah shall not be recognized as income. Instead, it has to be channeled to certain charitable bodies.

This resolution was issued by the SAC BNM by taking into consideration certain hadiths and fiqh maxims. The basis of rulings are :

1. Hadith of Rasulullah SAW that considers an intentional delay in debt payment by a person, who can pay, is a tyranny:

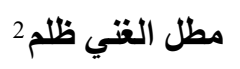

"Delay by a rich person (in payment of debt) is a tyranny."

2. Fiqh maxim:

$$
\text { لا ضرر ولا ضرار3 }
$$

"Neither harming nor reciprocating harm (in Islam). "

SAC BNM is of the view that, by referring to the maxim, late payment by the customer will create damage and harm to the Islamic financial institutions as they will suffer actual loss in terms of incurring additional expenditures, legal fees and other related costs as discussed earlier. Also, the delayed payment by the debtor will later affect financiers as they are unable to utilize the funds for other business purposes.

Therefore, the debtor should pay compensation to the losses suffered by the financier. The SAC BNM also based the resolution on another fiqh maxim.

3. Fiqh maxim:

$$
\text { الضرر يزال }
$$

"Whatever harm should be removed."

\footnotetext{
2 Al-Bukhari, Sahih Al-Bukhari (2nd edn, Al-Matba'ah al-Salafiyyah 1982).

3 Ibn Majah, In His Sunan, "Kitab Al-Aqdiyah Wa'l-Ahkam, Hadith 85.[228].

4 Al-Suyuti Al-Asybah wa al-Naza'ir, Dar Al-Kutub Al-'Ilmiyyah.[83-84].
} 
Based on this maxim, the SAC BNM opined that by imposing ta widh and gharamah on delayed payments, the harm or losses suffered by Islamic financial institutions would be mitigated while simultaneously disciplining the debtor to pay the debt within a specified time.

In 2006, International Shariah Scholars Dialogue was held in Putrajaya. One of the main issue discussed in the dialogue is the principles of compensation and penalty charges in dealing with loan default in Islamic finance. Prof.Dr. Muhammad 'Abd al-Razzaq al-Sayyid Ibrahim al-Tabataba'i in "Compensation for Damage and Fine for Late Payment of Debts: An Applied Study on Islamic Financial Institutions in the State of Kuwait" stated that there is difference in between compensation for damage and fine for late payment which in the former, the existence of damage is a requisite for compensation, whereas, in the latter, the fine is payable regardless whether damage exists or otherwise. ${ }^{5}$ In his paper, Prof. Muhammad 'Abd alRazzaq had discussed on the fine for the late payment of a debt. There are three types of fines, namely fine determined by actual damage; determining in detail, an agreed fixed amount equal to actual damage; and agreement on imposing fine more than actual damage.

Dr. Mohamad Akram Laldin, in his paper entitled "The Principles of Compensation and Penalty Charges in Dealing with Loan Default in Islamic Finance" had discussed whether such compensation is lawful or not. The contemporary scholars hold two different opinions regarding the ruling for compensating the creditor for the loss of capital gains and his profit due to the default of a debtor who is capable of settlement. ${ }^{6}$ The first opinion deals with the permissibility of imposing on the debt defaulter, who is capable of settling the debt, a financial compensation which should not be stipulated in the contract. The jurists

\footnotetext{
5 Muhammad 'Abd al-Razzaq al-Sayyid Ibrahim al-Tabataba'i, 'Compensation for Damage and Fine for Late Payment of Debts: An Applied Study on Islamic Financial Institutions in the State of Kuwait: Deliberation at the International Shariah Scholars Dialogue' (2006).[84].

6 Mohamad Akram Laldin, 'The Principles of Compensation and Penalty Charges in Dealing with Loan Default in Islamic Finance: Deliberation at the International Shariah Scholars Dialogue' (2006).[135].
} 
who are have issued a fatwa on this opinion include Shaykh Mustafa Ibn Ahmad al-Zarqa, Shaykh Abdullah Ibn Sulayman al-Mani, Dr. Muhammad al-Zuhayli, Dr 'Abd al-Hamid al-Bu'li, Shaykh Muhammad Khatir, and Dr. 'Abd al-'Aziz alQasar. $^{7}$ The second opinion deals with the impermissibility of imposing on the defaulting debtor, who is capable of settling the debt, a financial compensation not stipulated in the contract which is paid to the creditor for the loss of capital gains and the subsequent loss that accrue within the period of delay. ${ }^{8}$ This opinion was adopted by the Islamic Fiqh Academy affiliated to the World Muslim League, the Islamic Fiqh Academy affiliated to the Organisation of Islamic Conference (OIC), and the Shariah Council of the Accounting and Auditing Organisation for Islamic Financial Institutions (AAOIFI) to issue the fatwa. ${ }^{9}$ This opinion also held by several contemporary scholars that include Prof. Dr. Ahmad Fahmi Abu Sunna, Dr. Nazih Kamal Hammad, Dr ‘Ali al-Salus, Shaykh Taqi al-'Uthmani, Dr. Muhammad Shabir, Dr. Muhammad al-Qari and many others. ${ }^{10}$ Dr. Akram Laldin is inclined towards the first opinion which views the permissibility of obliging the debtor to pay the creditor a financial compensation for the loss of capital gain and profit due to his default in settling the debt. ${ }^{11}$

Dr. 'Ali Muhyi al-Din al-Qurah Draghi in his paper entitled "The Problem of Delayed Debts and Their Guarantees in Islamic Banks: A Shariah Study on Compensation for Deferred Loans" stated the negative effects of delayed payments on Islamic Banks. The implications include depriving them of benefits from payment of debts and gaining profits when delayed payments of investments occur. It causes the profit rate to be affected, and the Bank will not be able to compete with conventional banks which practice usury. ${ }^{12}$ Besides that, the focus on Islamic

\footnotetext{
7 ibid.[135].

8 ibid.[136].

9 ibid.[136].

10 ibid.[136].

11 ibid.[136-137].

12 Ali Muhyi al-Din al-Qurah Daghi, 'The Problem of Delayed Debts and Their Guarantees in Islamic Banks: A Shariah Study on Compensation for Deferred Loans: Deliberation at the International Shariah Scholars Dialogue' (2006).[162].
} 
banks will be more to rahn and daman transactions, which will adversely affect the giving of capital to customers due to the fear of delay in debt repayment. ${ }^{13}$ Other than that, the Islamic banks are forced to increase service charges, and this will increase difficulties in payments, and Islamic banks will be seen as presenting high costs compared to conventional banks. ${ }^{14}$

Hence, as an empirical study to the above literature, this study aims to discuss the imposition of late payment charges by way of $t a$ 'widh and gharamah and to find the law applicable in Malaysia. This study hopes to elaborate on the concepts of Shariah, Maqasid of Shariah, and Maslahah applicable to the imposition of ta'widh and gharamah. This study will also discuss on the permissibility of the imposition of ta'widh and gharamah and on how the imposition of ta'widh and gharamah is different from riba'.

The Concept of Shariah, Maqasid of Shariah and Maslahah Applicaple for the Imposition of Ta'widh and Gharamah

Maslahah and the maqasid (objectives) of the Shariah are among the important tools of Shariah as it concerns daily transactions and matters. To understand the Shariah, one needs to understand its objectives, which allows for flexibility and creativity in social policy. It includes permanent features and mechanisms for adapting changes and new developments according to time and space provided that its fundamentals such as 'aqidah (creed), ‘badah (worship), and akhlaq (morality and ethics) will never change. ${ }^{15}$

The Shariah has been defined literally as the road to the watering path, the straight path to be followed. Technically (Al-Qurtubi), it means the canon (law) of Islam, all the different commandments of Allah to humanity. ${ }^{16}$ Many Shariah texts

\footnotetext{
${ }^{13}$ ibid.[162].

14 ibid.[162].

15 Muhammad Hashim Kamali, Sources, Nature and Objectives of Shari ah (The Islamic Quarterly 1989).[215- 35].

${ }_{16}$ Mohamad Akram Laldin, Introduction to Shariah and Islamic Jurisprudence (Cert Publications Sdn Bhd 2006).[2].
} 
clearly state that the reasoning behind Shariah rulings is to benefit the people. For example, the Quran prohibits wine as it is the work of the devil, causing quarrels and instilling hatred and enmity among Muslims ${ }^{17}$ "The devil only wants to excite enmity and hatredbetween you in intoxicants and gambling and hinder you from remembrance of Allahand from prayer". ${ }^{18}$ This shows that Islam will never cause hardship to its people, but will protect them from evil.

The Maqasid of Shariah is essential to every Muslim around the world as it is designed to provide benefit and repel harm. It concerns both worldly affairs as well as those of the Hereafter. The former has been divided into four which are as follows: preservation of human self (nafs), preservation of posterity (nasl), preservation of intellect ('aql) and preservation of wealth (mal), all of which is meant to serve ourdeen (hereafter) according to Imam Al-Ghazali.

"The objective of the Shariah is to promote the well-being of all mankind, which liesin safeguarding their faith (din), their human self (nafs), their intellect ( ' $a q l$ ), theirposterity ( $\mathrm{nasl}$ ) and their wealth ( $\mathrm{mal}$ ). Whatever ensures the safeguard of these fiveserves public interest and is desirable". ${ }^{19}$

Maslahah, on the other hand, is one of the juristic devices that have been used to promote public benefit and prevent social evil or corruption. Maslahah means seeking benefit and repelling harm. The words maslahah and manfa 'ah are treated as synonyms. Manfa' ah (benefit or utility), however, is not the technical meaning of maslahah. What Muslim jurists mean by maslahah is the seeking of benefit and the repelling of harm as directed by the Lawgiver or Shariah..$^{20}$ Besides that, there is a hadith that is quoted on maslahah, which is as follows: "No harm shall be inflicted in Islam," which gives a meaning that there is no hardship in religion.

\footnotetext{
${ }_{17}$ Abdulazeem Abozaid dan Asyraf Wajdi Dusuki, 'The Challenges of Realizing Maqasid Al-Shari 'ah in Islamic Banking and Finance' (Research Gate, 2007) < https://www.researchgate. net/publication/237597634_The_Challenges_of_Realizing_Maqasid_al-Shariah_in_Islamic_Banking_and_Finance $>$.accessed 09 September 2017.

${ }^{18}$ Surat Al-Ma'idah, Verse No 91.

19 Abdulazeem Abozaid dan Asyraf Wajdi Dusuki (n 17).

${ }^{20}$ Mirza Vejzagic dan Edib Smolo, 'Maqasid Al Shariah in Islamic Finance: An Overview', Conference: Post-Crisis Economic Challenges for the Contemporary Muslim Ummah, At Universiti Sains Islam Malaysia (USIM), Nilai, Malaysia, Volume: Proceedings of the 4th Islamic Economic System Conference 2011 (iECONS 2011) (Research Gate 2011) <https://www.researchgate.net/publication/317063404_Maqasid_Al-Shari'ah_in_Islamic_Finance_An_Overview>.[4].
} 
According to Al-Ghazali, as for maslahah, it is essentially an expression referring to the acquisition of benefit or the repulsion of injury, but these only represent human goals. Maslahah, however, is the preservation of the ends of the Shariah.

Maslahah has been classified into three types based on its purposes, which are Daruriyyat (necessary interests/the essential), Hajiyyat (supporting needs) and Tahsiniyyat (embellishment). ${ }^{21}$ For Daruriyyat, if there is no protection against those interests, it may lead to chaos in society and the loss of everything we hold dear. These essentials are the self-interest upon which people depend, such as faith, life, intellect, posterity, and wealth. It is necessary to preserve these as it is related to a person's religious affairs, which if failed, would lead to the collapse of society. ${ }^{22}$ For example, the safety of life and intellect are secured by obtaining lawful means of sustenance or the enforcement of penalties, respectively. ${ }^{23}$

Furthermore, for Hajiyyat, these type of interests need to be protected under the law because failure to do so will lead to hardship. In other words, they are needed to ensure that life will be free from distress and predicament. For instance, Shariah granted Rukhsah in Ibadah to prevent hardship. ${ }^{24}$ Lastly, Tahsiniyyat, otherwise known as embellishments, refer to the interests, which if realized, will lead to refinement and perfection in the customs and conduct of the people. This includes, for instance, the observance of cleanliness in personal appearance. ${ }^{25}$

The main objectives of Shariah are to establish justice, eliminate prejudice, and alleviate hardship in society. This is manifested in the realisation of maslahah (public interest), which Islamic scholars have generally considered to be the allpervasive value and objective of the Shariah which is synonymous with compassion. Generally, Maqasid of Shariah is to preserve and protect maslahah of humanity. ${ }^{26}$

\footnotetext{
${ }^{21}$ Imran Ahsan Khan Nyazee, Outlines of Islamic Jurispridence (6th edn, Create Space Independent Publishing Platform 2003).[199].

${ }^{22}$ Asyraf Wajdi Dusuki and Nurdianawati Irwani Abdullah, 'Maqasid Al-Shari'ah, Maslahah, and Corporate Social Responsibility’ (2011) 24 The American Journal of Islamic Social Sciences.[32].

${ }^{23}$ Mohammad Hashim Kamali, Principles of Islamic Jurisprudence (2nd edn, Islamic Texts Society 1999).[272].

${ }^{24}$ ibid.[272].

25 ibid.

${ }^{26}$ Asyraf Wajdi Dusuki and Nurdianawati Irwani Abdullah (n 22).Op.Cit.[31].
} 
About maslahah, by referring to certain opinions of Muslim scholars, compensation is permitted for actual losses suffered by the Islamic banks. However, there are certain rules and conditions that must be followed for compensation to be imposed on the debtor. It is believed that this compensation is a kind of deterrence to the debtor so that the debtor will be more disciplined in paying his debt.

\section{Penalties/Late Payment Charges on Debtor Under Shariah Perspectives}

According to Muzakarah Cendekiawan Syariah Nusantara 2014, there are four types of fees which can be imposed by Islamic banks on debtors for default and delayed payment. They are as follows: ta'widh, gharamah, ujrah and nafaqah. In the context of Islamic banking and finance, $t a$ widh can be defined as compensation on the actual loss suffered by the financier or the bank due to late payment by the debtor. Meanwhile, gharamah is a penalty charge imposed due to late payment by the debtor without the financier or the banker needing to show the actual loss suffered. Ujrah is a concept of wages being imposed as services charges. Nafaqah, in the context of Islamic Finance, does not have the same view as that adopted under Islamic Family Law. According to figh muamalah, nafaqah refers to expenditures and costs due to services to complete a financing contract.

As far as our discussion is concerned, penalties or late payment charges imposed on the debtor by the creditor or financier are also known as ta widh and gharamah. Therefore, our discussion will only cover on ta widh and gharamah.

Al-Ta'Wid or al- 'iwad is defined as substitute, or counter-value. ${ }^{27}$ The Fiqh Academy Journal defines it as, "Payment of financial compensation or countervalue, which is obligatory as a result of loss caused to others". Thus, ta'widh is more specific than daman (surety for losses), which is based on the Shariah sources such as diyat (blood money), obligations (contracts), harmful act and yad al-daman

${ }^{27}$ Ibn Manzur, Lisan Al- 'Arab. Bayrut: Dar Ihya'Al-Turath Al-Arabi (9th edn, Dar Sader 1999).[474]. 
(liability). ${ }^{28}$ On the other hand, al-gharamah can be defined as what ought to be paid. ${ }^{29}$ Al-gharamah in Shariah and law is defined as a criminal punishment imposed by the state or the courts to protect the public interest. ${ }^{30}$ In simple words, ta widh means compensation and gharamah means penalty.

Gharamah should be distinguished from ta'widh. 'Abdul al-Qadr 'Awdah stressed out when he said, "What is acceptable is that the Shariah has imposed gharamah on some reprimand-worthy crimes in the forms of penalties. One of these is the punishment for stealing dangled dates by a penalty of paying back dates with double the price of what was stolen as the punishment which suits the theft". ${ }^{31}$

Dr. 'Ali Muhyi al-Din al-Qurah Daghi had discussed the term "gharamah" when he presented his paper in the Deliberation at the International Shariah Scholars Dialogue 2006. He stated that gharamah is a criminal punishment at all levels, a criminal penalty which covers all pillars of the punishment and elements of the criminal penalty. Thus, he stressed that the use of the word gharamah in a sense adopted by Islamic banks to protect its interests is not correct. ${ }^{32} \mathrm{He}$ claimed that it is inappropriate to use this word in Islamic banking. However, for financial purposes, he refers to the penalty imposed on delayed payment as gharamat al-Ta'khir. His arguments here only refer to the term used and not to the issue of the permissibility itself.

\section{Permissibility of the Imposition of Ta'widh and Gharamah}

The fundamental principles on the objective of Shariah, particularly in dealing with everyday life has been highligted earlier. Next, is to determine the maqasid of shariah of ta'widh and gharamah in dealing with late payment charges by the customer to the financier (the Islamic bank). As mentioned earlier, according to Imam

\footnotetext{
${ }^{28}$ Majma' al-Fiqhi al-Islami (Muslim World League), Majallat Majma' Al-Fiqh Al-Islami (14th edn, al-Majma' al-Fiqh al-Islami 1986).[510].

${ }^{29}$ Ibn Manr dan Muammad ibn Mukarram, Lisan Al-'Arab (12th edn, Bullag Misr al-Matb'ah al-Kubra al-'Amiriyah 1883).[436]; Muhammad b. Abi Bakr al- Razi, Mukhtar Al-Sihah (1st edn, Dar al-Fikr 1973).[198].

${ }^{30}$ Ali Muhyi al-Din al-Qurah Daghi (n 12).[178-179].

${ }^{31}$ Abd al-Qadr Awdah, al-Tashri'al-Jina'i, v.1.[705].

${ }^{32}$ Ali Muhyi al-Din al-Qurah Daghi (n 12).[182].
} 
Al-Ghazali, the objective of the Shariah is to promote the well-being of all humanity, which lies in safeguarding their faith (din), their human self (nafs), their intellect ('aql), their prosperity (nasl) and their wealth ( $m a l)$. Whatever ensures the safeguard of these five serves public interest and is desirable. In dealing with this section, a critical scrutinisation from the contemporary Islamic scholars and also from our Shariah Advisory Council of Bank Negara Malaysia (SAC BNM) point of views.

In the International Shariah Scholars Dialogue 2006, Dr. Mohamad Akram Laldin $^{33}$ has laid down the opinions of several contemporary scholars on this matter. Some of the contemporary jurists, such as Shaykh Mustafa Ibn Ahmad alZarqa ${ }^{34}$ Shaykh Abdullah Ibn Sulayman al-Mani,${ }^{35}$ Dr. Muhammad al-Zuhayli, ${ }^{36}$ Dr. 'Abd al-Hamid al-Bu 'li, ${ }^{37}$ Shaykh Muhammad Khatir, and Dr. `Abd al- 'Aziz al-Qasar have issued fatwas regarding the permissibility of imposing a financial compensation that has not been stipulated in the contract. The defaulter in this situation is one who is capable of settling the debt but intentionally delays repayment to the financier.

The debtor will pay the financial compensation in place of the capital gain lost during the period of the delay. According to Shaykh Al-Zarqa, the principle of compensating the financier for his loss resulting from the default of the debtor and from delay in settling the debt at the specified period is a principle that is acceptable in Islamic law. There is no injunction in the Shariah texts that deny the principle of compensation. The acceptability of this principle is subject to the condition that the debtor has no excuse in Shariah to delay repayment unless they are financially unable to.

\footnotetext{
${ }^{33}$ Mohamad Akram Laldin (n 6).[135].

34 Majallah Dirasat Iqtisadiyah Fiqhiyah, 'Hawla Jawaz Ilzam Al-Madin Al-Mumatil BiTa`wid Li`1- Da`in'.[11-20].

35 Majmu' al-Fatawa wa-Buhuth al-Shaykh, Matl Al-Ghaniy Zulmun Wa-Anna-Hu Yuhillu irdu-Hu Wa-'Uqubata-Hu.3.[266-191].

36 al-Muhasabah wa'l-Muraja'ah li'l-Mu'assasat al- Maliyah al-Islamiyah, Al-Ta'wid 'an Al-Darar Min Al-Madin Al-Mumatil”, Muqaddima Li-Hay 'at, Bi 'l-Bahrayn,.[81-82].

37 'Abd al-Hamid Mahmud al-Ba'li, Assasiyat Al-Amal Al-Masr Fi Al-Islami Al-Waqi Wa Al-Afaq: Dirasat Muqaranat Wa Mawazinat Li Al-Jawanib: Alqanunniyyat, Al-Masrifiyyah, Al-Fiqhiyyah (Qahirah: Maktab Wahbah 1990).[57-59].
} 
Shaykh Abdullah ibn Sulayman al-Mani', in supporting this permissibility, viewed that this particular stance of allowing compensation is supported by Shariah Maxims as well as direct and clear texts from the Quran and Hadith of the Prophet Muhammad SAW.38 The main objective of this permissibility is to avoid injustice to the owner of the property and also to uphold the necessity for fulfilling a contract and trust. The basis of this is also supported by few verses from the Quran as follows:

Quranic verses:

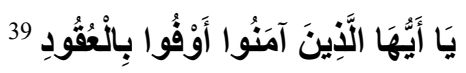

"Oh, you who believe! Fulfill your obligation".

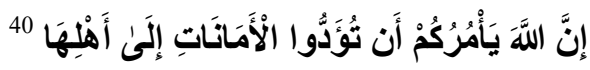

"Verily! Allah commands you that you should render back the trusts to those to whom they are due".

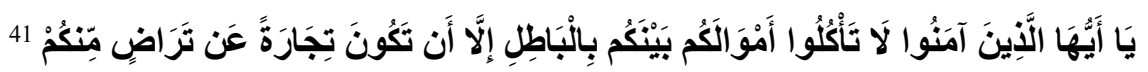
"Oh you who believe! Eat not up your property among yourselves unjustly except it be trade amongst you by mutual consent".

The above verses had highlighted the necessity of fulfilling contract, rendering back trust, the prohibition of devouring property unjustly and delay in meeting with the deadline without the consent of the owner of the property because this is considered as eating up property or benefiting from it unjustly. Therefore, the defaulter becomes unjust for the loss incurred by the owner of the property, and he also responded for the loss incurred by the owner due to his default.

Next, the imposition of ta'widh and gharamah is also to prohibits any harms and should there any harm occurred; it is a necessity for it to be removed. In supporting this objective, the Jurist is also referring to the Fiqh maxim derived from few Hadith of the Prophet SAW narrated and reported by the companions:

\footnotetext{
${ }^{38}$ Majmu` al-Fatawa wa-Buhuth al-Shaykh (n 36).[163].

${ }^{39}$ Surah Al-Maidah, verse no.1

${ }^{40}$ Surah Al-Nisa' verse no.58

${ }^{41}$ Surah An-Nisa', verse no.29
} 


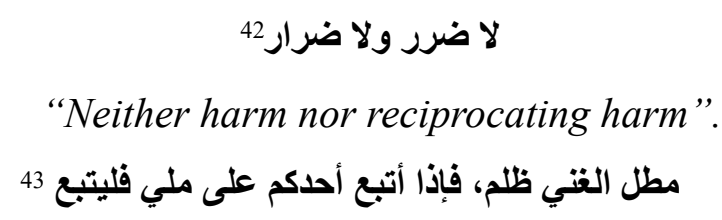

"Delay by a rich person (in payment of a debt) is a tyranny." So, if your debt is transferred from a rich debtor, you should agree (to the transfer)".

The above Hadith had been referred to as Fiqh maxim and its indicated the prohibition of harm and the necessity for its removal. The lost that befalls the creditor could not be removed except by financial compensation for what they have lost from its capital gain during the period of default.

It was also reported by 'Amru ibn al-Shurayd who narrated from his father who in turn narrated from the Prophet SAW, "Procrastination by the solvent makes lawful his honor and punishment". ${ }^{44}$ This hadith highlighted that the default in settling the debt by one who is capable of settling it is unjust and the culprit deserved disgrace and punishment. The types of ta'zir punishment include financial ta'zir, which is legitimate and is of various types. The first types are for the damage and the second types relate to the changes (in the condition of the asset), and the third type relates to the transfer of the ownership to others including compensation to the creditor for the lost opportunity of his capital gained during the period of the default.

One of the most important principles adopted by the Shariah and its general objectives is the dissimilarity between the trustworthy and the betrayer, between the obedient and the disobedient, between the just and the unjust. No doubt, delaying the right of its owner intentionally and defaulting it without any Shariah plea is unjust and wrong as provided in the Shariah texts. It is harmful to the owner of the right to deny him his capital gain. If the defaulter is not obliged to compensate the owner of the right for such losses, it will result in equating the disobedient to one

\footnotetext{
${ }^{42}$ Ibn Majah (n 3).

${ }^{43}$ Al-Bukhari (n 2).

44 Abu Bakar Ahmad Al-Bayhaqi, Al-Sunan Al-Kubra (6th edn, Dar al-Kutub al-Ilmiyah 2010).[85].
} 
who is trustworthy and just. Hence, both of them will be considered as fulfilling their obligations, which will only encourage the defaulter to default further.

\section{How to Treat Defaulting Debtor under Shariah}

As far as the debtor is concerned, there are two types of debtors that need to be considered when it comes to imposing compensation or penalty charges due to the delayed payment. It is this distinction that demonstrates the infusion of the objectives of Shariah (i.e., the Maqasid), such as equity and justice, in the emergence and development of the present-day Islamic banking and finance framework. Islam has laid down a great duty on debtors to fulfill their obligations. There is no excuse in Shariah that requires or justifies the discharge of debts unless an exceptional case presents itself such as death or fraud etc. This is embodied in the Quranic verse:

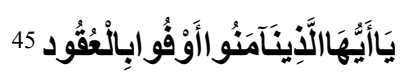

"Oh, you who believe! Fulfill your obligation”.

This principle is so universal that it has also been laid down in Malaysian case law as can be seen in the case of CIMB Islamic Bank Bhd v LCL Corp Bhd \& Anor ${ }^{46}$ where Mohd Zawawi J observed as follows:

"The general principle of law, of course, is that a party who signs a written contract is bound by the terms of the contract, except in the limited case where fraud, undue influence, or misrepresentation may be established. This rule is so strict that even if a party to a contract has not read the contents of a contract, he is held to be bound by its terms".

Failure on the part of one party to fulfill their obligations is a breach of contract. This, in turn, allows the innocent party to take legal action to enforce his/her rights, either by forcing the party in the wrong to fulfill the contract or insist that they compensate any losses suffered by the innocent party as a result of the breach. Either way, the purpose of such remedies is restitution, i.e., to restore the wronged party to the position they were in before the breach.

\footnotetext{
${ }^{45}$ Surah Al-Maidah, verse no. 1

${ }^{46}$ [2011] MLJU 1134
} 
This being said, however, if repayment is delayed in a debit transaction, any remedy enforced should not take the form of monetary compensation, but should rather be a method of compelling the debtor to pay his/her dues. This is because debt transactions fall under the category of uqud tabarru'at (charitable contracts), and thus any profit made over and above the loan amount will amount to riba. As Allah has stated:

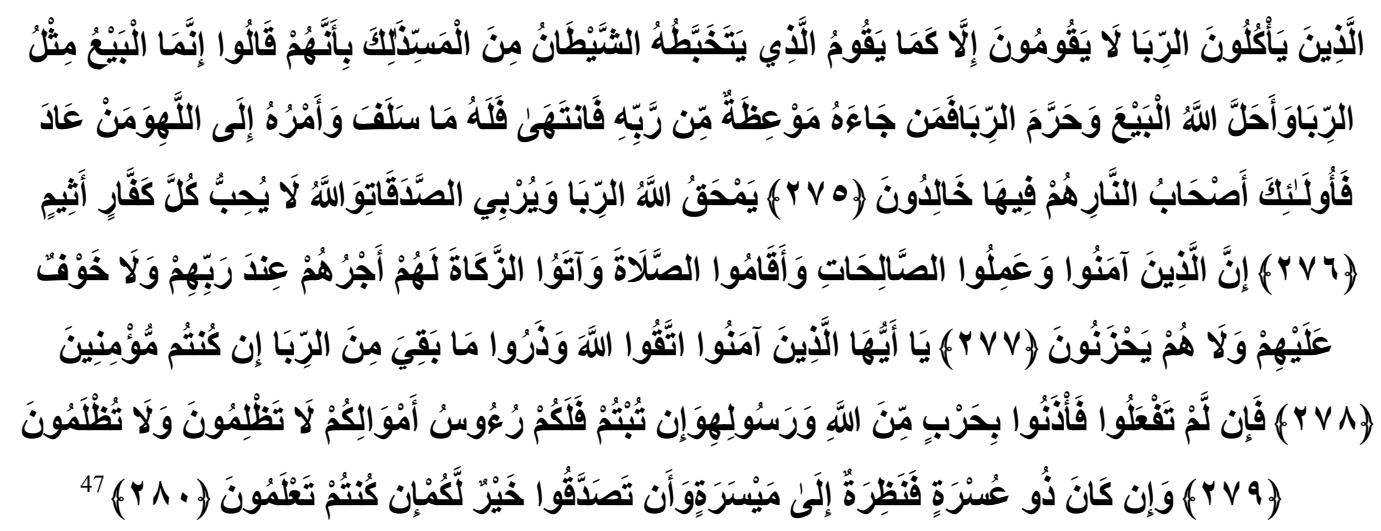

"Those who consume interest cannot stand [on the Day of Resurrection] except as one stand which is being beaten by Satan into insanity. This is because they say, "Trade is [just] like interest." But Allah has permitted trade and forbidden interest. So whoever has received an admonition from his Lord and desists may have what is past, and his affair rests with Allah. But whoever returns to [dealing in interest or usury] - those are the companions of the Fire; they will abide eternally therein. Allah destroys interest and gives increase for charities. And Allah does not like every sinning disbeliever. Indeed, those who believe and do righteous deeds and establish prayer and give zakah will have their reward with their Lord, and there will be no fear concerning them, nor will they grieve. O you who have believed, fear Allah and give up what remains [due to you] of interest if you should be believers. And if you do not, then be informed of a war [against you] from Allah and His Messenger. But if you repent, you may have your principal - [thus] you do no wrong, nor are you wronged. And if someone is in hardship, then [let there be] postponement until [a time of] ease. But if you give [from your right as] charity, then it is better for you, if you only knew."

The permissible remedies offered in these Quranic verses for non-repayment of debts include either generously discharging the debtor giving an extension of time for repayment. However, these can only be applied to debtors who are in, as the verses state, 'strained circumstances,' i.e., genuine debtors. For this article, a

\footnotetext{
${ }^{47}$ Surah Al-Baqarah verse no. 275-280.
} 
genuine debtor can be defined as someone who defaults because of necessity or a person whose financial situation is such that even with the best of intentions he lacks the means of paying.

According to Dr. 'Ali Muhyi al-Din al-Qurah Daghi, ${ }^{48}$ there are two major reasons for customers to delay payment genuinely. They may either have some assets, but the amount may be insufficient to pay all their debts, or the debtor may not own any assets at all. As can be seen above, the Quran is explicit when it says that these kinds of individuals deserve compassion and should, therefore, be treated with leniency. The Shariah, after all, is characterized by leniency and softness in realizing its objectives rather than harshness and rigidity. As in the Quran, Allah states:

$$
\text { يُرِيدُ اللَُّ بِعُمُ الْيُسْرَ وَلَا يُرِيدُ بِكُمُ الْعُسنر } 49
$$

"Allah desires for you ease; He desires not hardship for you."

However, what about debtors who are well equipped to pay off their debts but do not? Should they not be penalized for their indiscretions? According to some contemporary Muslim scholars like Shaykh Mustafa Ibn Al-Zarqa, Shaykh Muhammad Sadiq Ad-Dharir, and Abdul Hamid Al-Sa'ih, it is permissible to punish recalcitrant defaulters by forcing them to pay some form of compensation to their creditors. This is based on several sources of Islamic law, the first of which is the hadith where the Prophet SAW was narrated saying:

$$
\text { مطل الغني ظلم } 50
$$

"Delay by a rich person (in payment of a debt) is a tyranny."

In another hadith, the Prophet SAW also mentioned:

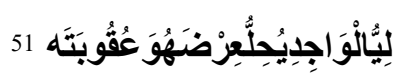

"Procrastination by the solvent makes lawful his honor and punishment."

Classical jurists have often interpreted the word 'punishment' here as physical punishment. However, a more liberal approach has been taken by contemporary

\footnotetext{
48 'Ali Muhyi al-Din al-Qurah Daghi (n 12).[157].

${ }^{49}$ Surah Al-Baqarah, verse no. 185.

${ }^{50}$ Al-Bukhari (n 2).[175].

${ }^{51}$ Abu Bakar Ahmad Al-Bayhaqi (n 49).[85].
} 
scholars to include monetary punishment as well. For instance, Shaykh Muhammad Sadiq Ad-Dharir said:

"It is permissible to force a solvent procrastinating debtor to pay compensation in favor of the creditor who suffered from an unjustifiable delay in performance. This is because this type of debtor is an unjust person as declared by the hadith that say default of a solvent debtor is an injustice. Therefore, the situation of this debtor is similar to the situation of the usurper who has been held liable by the majority of jurists to compensate the advantage or usufruct of tangible properties on top of refunding the usurped property to the owner". ${ }^{52}$

This is because when debtors delay in settling their financing on purpose, there is a very high chance that banks will end up losing the prospective profit it could have otherwise received if it had used the funds in question for investment purposes. It will, additionally, need to bear the actual loss of issuing notices and letters of demand, legal fees, and other related costs for the purpose of recovering the debt. It must be remembered here that banks and other financial institutions are in fact, financial intermediaries and not charitable institutions. Thus, they cannot run at a loss. Not only do these financial institutions need customers to pay their debts on time, but they also need some compensation for the loss they have suffered if they are to compete at the same level as their conventional counterparts mean of paying.

Other negative effects of delayed payments on Islamic banks have been explained in great detail by Dr. 'Ali Muhyi al-Din al-Qurah Daghi in his article titled "The Problem of Delayed Debts and their Guarantees in Islamic Banks: A Shariah Study on Compensation for Deferred Loans". ${ }^{53}$ These include Islamic banks moving to more rahn and daman based transactions, which will, in turn, cause banking services to cater only to a certain qualified class in society who can produce guarantees. Islamic banks will also be forced to increase service charges if clients continue to default on their financing.

52 Mohamed Burhan Arbouna, 'Compensation for Delay in Financial Obligations with Special Reference to Default on Debt Payment: A Comparative Islamic Legal Study' (2004) 3 Majallah Abhath Al-Iqtisad Al-Islami.[337].

53 'Ali Muhyi al-Din al-Qurah Daghi (n 12).[157]. 
As the former chief justice of Malaysia, Tun Abdul Hamid Mohamad also says in his article titled "Late Payment Charge on Judgment Debts Arising from Financial Transactions by Shariah ". 54

"In late 1980s Islamic banking was introduced. It grew by leaps and bounds over the next thirty years. Like the conventional counterpart, customers began to default, and civil suits were filed in courts. I understand that, unlike conventional banks, Islamic banks did not ask the court to make an order for interest after judgment as interest is prohibited under the Shariah.

However, that practice led to two negative effects. First, Islamic banks were losing money because they were deprived of the "interest after judgment" which conventional banks were entitled to, which could cover the legal and related expenses in the execution of the judgment and also the loss incurred as a result of the delay in settlement of the judgment debt. Secondly, there is another aspect, which is worse. As the judgment debts of Islamic banking cases carry no after judgment interest, it was in the interest of judgment debtors to delay the settlement of judgment debts of Islamic banking cases. It was more profitable for them to settle the judgment debts of conventional banks first. In other words, they would gain by delaying the settlement of judgment debts in Islamic banking cases and the longer they were able to delay, the more they would gain.

"While Islamic banks suffered silently under the belief that "that is the requirement of Shariah', the defaulting customers, Muslims, and nonMuslims, were enjoying "the benefits of Shariah".

Although this article refers to judgment debts, in particular, these negative effects can also be attributed to the default practices prevalent among customers who have taken financing as well. Thus, the only way to solve this problem of people 'enjoying the benefits of Shariah' (i.e., by settling their loans with conventional banks first before settling their financing with Islamic banks) without facing any consequences is to implement compensation and penalties. It is needed for the interest of the public, i.e. maslahah.

However, maslahah also dictates that when imposing late payment charges, the bank should take into the consideration the customer's financial capability, which as mentioned time and time again is essential teaching propagated by the

54 Tun Abdul Hamid Mohamad, 'Late Payment Charge on Judgment Debts Arising from Financial Transactions' (2013) < http://www.tunabdulhamid.my/index.php/speech-papers-lectures/ item/483-late-payment-charge-on-judgment-debts>.accessed 17 September 2017. 
Quran. Thus, recalcitrant debtors should be penalized, whereas genuine debtors should be treated with leniency. This way, the interests of both parties are protected, and a balance is accorded; which is part and parcel of the Maqasid of Shariah.

\section{How the Imposition of Ta'widh and Gharamah Would Constitute to Riba'?}

As discussed earlier, a number of Islamic scholars and jurists including Shaykh Mustafa Al-Zarqa', Shaykh Muhammad Sadiq al-Dharir, the Religious Supervisory Board of the Islamic Bank of Jordan and most of Shariah Committees of Islamic banks in Malaysia are of the view that compensation is allowed, and the bank can utilize it as an income. The basis of their argument is maslahah mursalat, which is to prevent the public from taking advantage of and intentionally delaying their payments to Islamic banks. This paper will also touch on both the permissible and impermissible views because there are several Islamic scholars and jurists who are against this ideology, their main concern being that the imposition of compensation may lead to riba.

\section{Impermissible view}

The scholars who take this view argue that the Hadith, which mentions that procrastination on the part of a rich man will compromise his honor does not specifically indicate the permissibility of compensation. In fact, according to them, there is no Hadith or scholarly view that can be interpreted to allow for compensation. ${ }^{55}$ Even the Hadith of "Neither harming nor reciprocating harm (in Islam)" ${ }^{56}$ could not be referred to as removing one harm does not include substituting it with another.

The resolutions of the Islamic Fiqh Academy affiliated to the World Muslim League stipulate, "If a creditor stipulates to the debtor or imposes on him to pay an amount of money as a specific financial penalty or a certain percentage if he delays in settling the debt within the specified period between them, it is a condition or a loan that is invalid. It should not be fulfilled because this is essentially the riba jahiliyyah which the Al-Quran was revealed to prohibit". Riba jahiliyyah is a type

\footnotetext{
${ }_{55}$ Ali Muhyi al-Din al-Qurah Daghi (n 12).

${ }^{56}$ Ibn Majah (n 3).
} 
of late payment charge that is generally acknowledged by scholars to be prohibited. This type of riba was practiced in pre-Islamic Arabia during the time of jahiliyyah or ignorance. Riba jahiliyyah occurs when Islamic banks ask debtors to settle their debts on time with the option for postponement as long as the debt is increased. The prohibition of riba jahiliyyah also has a moral basis in that a debtor in difficulty should be given respite instead of having further hardship imposed upon him.

This view is adhered to by a significant number of scholars, who argue that Prophet Muhammad (PBUH) was well aware of the possibility of default in payments. And yet there has been no record of his ever having provided a riba exemption for it. Looking also at the views of Islamic scholars such as Dr. Zaki al-Din Sha'ban, Dr. Nazih Hammad, Dr. 'Abd Al-Nasir Al-Attar, Dr. Shabir and economist Dr. Rafiq Al-Misri ${ }^{57}$ argued as follows:

1. Compensation is not permissible as stipulating compensation for the delay of payment in debt repayment is riba;

2. Implementation of compensation is a ruse to achieve riba. Economist, Dr. Rafiq Al-Misri commented on the view of Al-Zarqa, "concerning this suggestion, I fear that it would facilitate the practice of Riba where another term such as punishment due to a delay of payment is used in place of the forbidden riba. If this compensation and its compensation clause are allowed, there is a possibility of transgressing limit". ${ }^{58} \mathrm{He}$ also mentions that what had once feared has now actually materialized because after he left his position as a Shariah Advisor, one of the banks he was supervising finally obtained consent from its Shariah Committee to stipulate both compensation and gharamah (penalty) for delayed payment. The Islamic Committee consented on the condition that it will be channeled and spent on public welfare.

3. Furthermore, the bank's management also obtained consent from its Shariah Committee to use a part of the funds for their processing fees and directed its officers to compute the processing fee so that it equaled the compensation collected by them. As a result, the entirety of the compensation that was imposed went to the bank's officers;

4. Financial compensation for delayed payment in this day and age is very different from the practice that existed during the era of Prophet Muhammad (PBUH), which was known as the era of the righteous caliphs. The teachings of Islam were adhered to strictly here, and punishing rich procrastinating debtors took place by way of Ta'zir, such as imprisonment.

\footnotetext{
${ }^{57}$ Muhammad Al-Qari in his paper presented at the $8^{\text {th }}$ International Islamic Fiqh Conference.[6].

${ }^{58}$ Paper by Shaykh Mustafa Al-Zarqa published in Majallah Abhath Al-Iqtisad Al-Islami, v.2.[154].
} 


\section{Permissible View}

Among the scholars who are in favor of the imposition of compensation are Shaykh Mustafa Al-Zarqa, Shaykh Muhammad Al-Siddiq Al-Darir, and Shaykh Abdullah bin Mani. These scholars argue that compensation for delayed payment in debt is dissimilar to riba, which leads to obvious usury.

Also, compensation is analogous to usurpation (ghasb) in that both share the same 'illah, which is obstructing the use of the property and exploiting it. Imam Shafii and Hanbali are of the view that the seized property should be compensated. In the case of a delayed payment of the financing amount, failure of the debtor to settle the financing amount within the stipulated period will have a bad impact on the creditor, who has lost the opportunity to utilize the funds for business purposes. Al-Zarqa observed that compensation is payable for losses the parties incur in a business transaction due to the disruption of the business. Therefore, due to the change in times and circumstances, the imposition of compensation may be required to secure economic interests.

To conclude this issue, the view that compensation for the loss of default could lead to Riba should not be an issue. The issue of riba increment is without any counter value. It is the result of an agreement between the creditor and the debtor for the deferment in settling the debt in place of an extension of time. In contrast, compensation is for the benefit of the creditor on what the creditor has lost without his approval. Next, the Riba increment is stipulated in advance and determined based on future delay mutually agreed upon by the customer and the bank. While compensation is to remove justice that befalls the owner of the capital due to delay that had occurred in the past without the consent of the bank. The percentage of the riba increment is made known to both parties from the beginning of the contract whereas, in compensation, it is not possible to know the percentage in advance however it is determined based on the profit loss during the period of default. ${ }^{59}$

\footnotetext{
${ }^{59}$ Al-Shaikh al-Mani, Mushkilat al-duyun al-muta'akhirah fi al bunuk al-Islamiyyah, Majallah Majma al-Fiqh al-Islami, $14^{\text {th }}$ Meeting.[543-544].
} 


\section{Conclusion}

It should be noted that our current Islamic financial situation has become advanced, and this complex operation did not exist in the past era. Therefore the nature of the defaulter in the past era might be the difference from what we find now. Commercial matter nowadays has become more demanding. Therefore if ta' widh and gharamah were not imposed in our present time, the customer will take advantages on this and will lead to capital loss of the Islamic bank institution. It will cause a major effect on the whole economic development and will create serious difficulties, especially to the Islamic financial institution.

Also, the Islamic jurist has agreed that the issue of punishment for default in financing and delaying the capital that matures at the disposal of those who are required to return it to their owner is included among ta'zir punishment. The general meaning of the term punishment includes a financial penalty. The general text that considers financial penalty as the means of ta'zir is clear and direct. Ibn Qayyim mentioned that the Scholars have deferred on the financial penalty. He inquired whether its ruling is abrogated or prevalent? The correct answer is that the ruling varies with maslahah (public interest). It is referred to the ijtihad of the Imams at every time and the place based on the maslahah since there is no evidence for its abrogation. It was practiced by the righteous Khulafa' and the Imams after them. ${ }^{60}$ Shaykh al-Islam Ibn Taymiyah also mentioned that a financial penalty is one type of Ta'zir.

Trust and the general level of morality in modern societies is undoubtedly not the ideal standard. The practical experience of many Islamic banks shows that if an individual is given free rein, they will become powerful. Many of them are inclined towards default in settling debt because of their secured position. If we tell the Islamic bank to overlook this reality, they would not be able to compete with the conventional bank because the conventional bank system has the means to motivate the debtors to settle their debts in time due to customer awareness of the compounding interest for late payment.

\footnotetext{
${ }^{60}$ Ibnu Qayyim Al Jauziyah, I'lam Al-Muwaqqi'in 'an Rabb Al-Alamin (2nd edn, Pustaka Azzam 2000).[98].
} 
Therefore, we are also of the view that the mechanism of ta'widh and Gharamah that is currently implemented is different from any penalty charged in conventional banks, which is riba. Also, the imposition of ta'widh and gharamah by Bank Negara is in line with the maqasid of shariah, which it is important to protect religion of Islam by ensuring sustainability of Islamic Banking.

\section{Bibliography}

Abdulazeem Abozaid dan Asyraf Wajdi Dusuki, 'The Challenges of Realizing Maqasid Al-Shari'ah in Islamic Banking and Finance' (Research Gate, 2007) $<$ https://www.researchgate.net/publication/237597634_The_Challenges of_Realizing_Maqasid_al-Shariah_in_Islamic_Banking_and_Finance.> accessed 09 September 2017.

Abu Bakar Ahmad Al-Bayhaqi, Al-Sunan Al-Kubra (6th edn, Dar al-Kutub alIlmiyah 2010).

Al-Ba'li 'Abd al-Hamid Mahmud, Assasiyat Al-Amal Al-Masr Fi Al-Islami Al-Waqi WaAl-Afaq: Dirasat Muqaranat Wa MawazinatLiAl-Jawanib: Alqanunniyyat, Al-Masrifiyyah, Al-Fiqhiyyah (Qahirah: Maktab Wahbah 1990).

Al-Bukhari, Sahih Al-Bukhari (2nd edn, Al-Matba`ah al-Salafiyyah 1982).

Al-Muhasabah wa '1-Muraja 'ah li'1-Mu assasat al- Maliyah al-Islamiyah, $A l-T a$ 'wid 'an Al-Darar Min Al-Madin Al-Mumatil”, Muqaddima Li-Hay'at , Bi'lBahrayn,Al-Suyuti Al-Asybah wa al-Naza'ir, Dar Al-Kutub Al- Ilmiyyah.

Ali Muhyi al-Din al-Qurah Daghi, 'The Problem of Delayed Debts and Their Guarantees in Islamic Banks: A Shariah Study on Compensation for Deferred Loans: Deliberation at the International Shariah Scholars Dialogue' (2006).

Asyraf Wajdi Dusuki and Nurdianawati Irwani Abdullah, 'Maqasid Al-Shari'ah, Maslahah, and Corporate Social Responsibility’ (2011) 24 The American Journal of Islamic Social Sciences.

Bank Negara Malaysia, Shariah Resolutions in Islamic Finance (2nd edn, 2010).

Fiqhiyah MDI, 'Hawla Jawaz Ilzam Al-Madin Al-Mumatil Bi-Ta`wid Li’1- Da in’

Ibn Majah, In His Sunan, “Kitab Al-Aqdiyah Wa'l-Ahkam, Hadith 85.

Ibn Manr dan Muammad ibn Mukarram, Lisan Al-'Arab (12th edn, Bullag Misr al- 
Matb'ah al-Kubra al-'Amiriyah 1883).

Ibn Manzur, Lisan Al-'Arab. Bayrut: Dar Ihya' Al-Turath Al-Arabi (9th edn, Dar Sader 1999).

Ibnu Qayyim Al Jauziyah, I'lam Al-Muwaqqi'in 'an Rabb Al-Alamin (2nd edn, Pustaka Azzam 2000).

Imran Ahsan Khan Nyazee, Outlines of Islamic Jurispridence (6th edn, Create Space Independent Publishing Platform 2003).

Kamali MH, Principles of Islamic Jurisprudence (2nd edn, Islamic Texts Society 1999)

Majma' al-Fiqhi al-Islami (Muslim World League), Majallat Majma' Al-Fiqh AlIslami (14th edn, al-Majma' al-Fiqh al-Islami 1986).

Majmu` al-Fatawa wa-Buhuth al-Shaykh, Matl Al-Ghaniy Zulmun Wa-Anna-Hu Yuhillu `irdu-Hu Wa-'Uqubata-Hu,3.

Mohamad Akram Laldin, Introduction to Shariah and Islamic Jurisprudence (Cert Publications Sdn Bhd 2006).

_- 'The Principles of Compensation and Penalty Charges in Dealing with Loan Default in Islamic Finance: Deliberation at the International Shariah Scholars Dialogue' (2006).

Muhammad 'Abd al-Razzaq al-Sayyid Ibrahim al-Tabataba'i, 'Compensation for Damage and Fine for Late Payment of Debts: An Applied Study on Islamic Financial Institutions in the State of Kuwait: Deliberation at the International Shariah Scholars Dialogue' (2006).

Muhammad b. Abi Bakr al- Razi, Mukhtar Al-Sihah (1st edn, Dar al-Fikr 1973)

Muhammad Hashim Kamali, Sources, Nature and Objectives of Shari ah (The Islamic Quarterly 1989).

Mohamed Burhan Arbouna, 'Compensation for Delay in Financial Obligations with Special Reference to Default on Debt Payment: A Comparative Islamic Legal Study' (2004) 3 Majalah Abhath Al-Iqtisad Al-Islami.

Mirza Vejzagic dan Edib Smolo, 'Maqasid Al Shariah in Islamic Finance: An Overview', Conference: Post-Crisis Economic Challenges for the Contemporary Muslim Ummah, At Universiti Sains Islam Malaysia (USIM), Nilai, Malaysia, Volume: Proceedings of the 4th Islamic Economic System 
Conference 2011 (iECONS 2011) (Research Gate 2011) <https://www. researchgate.net/publication/317063404_Maqasid_Al-Shari'ah_in_Islamic Finance_An_Overview>.

Tun Abdul Hamid Mohamad, 'Late Payment Charge on Judgment Debts Arising from Financial Transactions' (2013) <http://www.tunabdulhamid.my/index. $\mathrm{php} / \mathrm{speech-papers-lectures/item/483-late-payment-charge-on-judgment-}$ debts.> accessed 17 September 2017.

HOW TO CITE: Zuhaira Nadiah Binti Zulkipli, 'Late Payment Penalty: Ta'widh and Gharamah Imposed to Debtor from the Shariah Perspective ' (2020) 35 Yuridika. 